\title{
PROBLEMS IN COMPANY LAW
}

\section{A SYMPOSIUM}

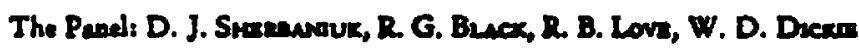

1. What considerations determine whether or not a company should be incorporated?

When this problem is being discussed the following questions should be answered: who are the individuals involved, what is their presene relationship, what are their ages, how many are there and what type of busineas is to be carried on?

People in business tend to fail to realize that a company can carry on business through a limited partnership. In special situations this type of organization is satisfactory and it should nor be overlooked as it provides for limited liability insofar as the special partmer is concerned. It should be noted however, that auch a business form would have no starus outside Alberta.

It may be your opinion that the present relationahip between the owners of a business is such that a detailed form of agreement is necessary. In the case of many father and son businesses it will be found that the parties find difficulty in formulating a clear agreement which adequately protects the rights and privileges of all concerned. The corporate form of business, with its rights of ownership being represented by shares, is as excellent way to carry on such a business and prevent many prospective disagreements.

The most important aspect and main advaneage of incorporation is limited liability. A member of a company cannot be compelled to contribute in excess of the amount remaining unpaid on his shares. It is not correct to say that the company has limited liability, its liability is akin to that of any other legal entity, the full extent of its physical resources. The true significance of limited liability was revealed in Saloman v. Saloman when the major ahareholder succeeded in protecting much of his investment through the issue of debentures. As Lord Watson stated in that case, "2 crediror who will nor take the trouble to use the means which the statute provides for enabling him to protect himself, must bear the consequences of his own negligence." This apparent advantage over unwary ereditors must be explained to the principal shareholdet. Many institutions will require a pledge or hypothecation of any securities held by the principal sharcholder and a postponement of his elaims to that of the institution.

The ability to finance is an important feature of the corporation. There are a great many forms of "ownership" available and this is as great an advantage to the small business as it is to the large. A great many different interests can be accommodated: those who seek a prior claim, convertibility, preference, features of redemption, security can all be accomodated in some form ot other. 
A full appreciation of your client's posicion can result an your advisuzy: him to choose a form of organization which will be most advantagepus with regard to income and succession dury rax. If we compare a single proprietorship with a corporation, and the profies are left in the business then we will see that money is saved by using the corporate form once the income excecds $\$ 8,000.00$ per year. The governing considerations depend upun the situation of the individual client but income tax and succession duty must be conside:ed in determining the relative advantage of the different forms of business.

2. What considerations determine whether a company should be incorporated as a Dominion or Alberla Company?

The main consideration is, where does the proposed company intend to carry on business?

The provinces are given power to create companies "with provincial objects" under section 92 of the B.N.A. Act. Also, under s.9(2) of the Alberts Companies Act a company is given capacity to accept powers to effect its objects outside the province. It is neceasary to consider the other places where your company might carry on business and then to examine the starutes of those jurisdictions to see if an Alberta company could carry out business in those jurisdictions. One must look for a provision similar to our 8.140:

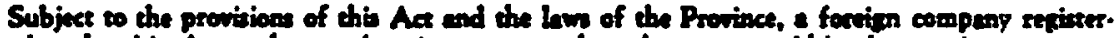
ed under this Aet and noe echerwies empowared to do 20 may within the province carn on

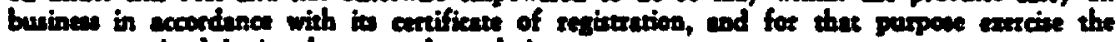
powern costained in in charter and segulations.

The Acts of the Provinces of Britich Columbia, Saskatchewan and Manitoba contain what appears to be an adequate provision. Ontario and Quebec are not so explicite in their company provisions and Nova Scotia. Prince Edward Island and New Brunswick do not have comparable sections to our s.140.

The jurisdictional problem does not confront a Dominion company. Provincial legislation cannoc deatroy the status of a Dominion company. The provinces cannot pass legislation which is prohibitive with respect to Dominion companies. Moreover Dominion companies may be in a more favourable posirion if recognition by a foreign jurisdicton is desired. It is interesting to note that Dominion Letters Patent authorize the company to carry on business throughout Canada and elsewhere.

The jurisdictional problem may determine the form of company. General. ly speaking, if the company is so do business throughout Cansda, a Dominion company is preferable. The problem of carrying on business in forcign count. ries is usually solved by setting up a wholly owned subsidiary in the foreign juriediction.

Another factor is cost. As cariffs covering fees generally vary with author. ized capital it is necesary to have particulars of the capienl before an accurate estimate can be made. The fees in some provinces vary acconding to the capital investment in the particular provinces. If we cake an Alberta company with minimum authorired capital and regieter or license it in all the provinces the approximate cost would be $\$ \mathbf{4 0 0}$, while it would cost approximately $\$ 6 \mathrm{Cr}$. to incorporate a Dominion company and put it in a position to carry on busi. 
ness in all provinces. An Alberta company authorized to carry on business in the western provinces would cost about $\$ 205$, while a Dominion company in the same position would cost about \$400.

A third consideration is the objects of the proposed company. In the Alberta Act there is no restriction or limitation dealing with object clauses. There is a limitation on Dominion companies: the Secretary of Sate is responsible for an examination of the objects clauses, and the government order-in-council states;

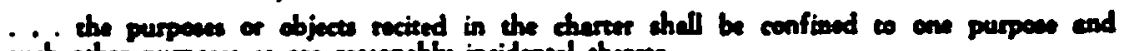
such other purposes as are reacably incidentel therro.

There are other minor considerations which may determine which form of company to choose. For example, a promoter may not desire a Daminion Company since the Dominion Companies Act atntes that a director shall not speculate for his own personal account, directly or indireetly, in the shares or securities of the company. There is no similar provision in our Act. One should become familiar with all the details concerning the purposes and objects of the company and then consider the differences in the Acts.

\section{What considerations determine the choice of a company's name?}

Generally speaking the name of a company should be descriptive of its objects or business with the exception that if a company is formed solely for investment or holding purposes it may contain the surname of a principal shareholder.

S.12(1) of the Act sets out some prohibitions. A company is not to be registered with (a) an identical name to that of another company even if its purpose be entirely different and ies place of operations in a different part of the world; (b) a name which in the opinion of the Registrar is calculated to deceive, even if the name is that of a person who is to be a shareholder in the company; (c) names restricted by the practice of the Registrar. A descriptive word cannot be claimed as a monopoly and instances here are, "Western", "Plains," and "Prairie".

The Registrar has set down certain general principles: (a) the name must not be misleading. (b) a name cannot be allowed which suggests a connection with the Crown. a member of the Royal Family, or with a departenent of government; (c) names such as "Imperial", "Commonwealth", "National", "International", "Co-Operative", and Society are generally not allowed; (d) names such as "Bank", "Banking", and "Trust" are not generally allowed and if it is the name of a shareholder he must be a major shareholder or director, (e) If a proposed name is a registered trade mark the consent of the owner of the trade mark should be produced.

The question has been raised as to whether a company can carry on business under a trade name without in any way publicizing the fact that the business is owned by a limited company. It would appear that $5.77(1)$ (c) answers that question in the negative. It may be that individuals signing on behalf of such a business may be prepared to accept unlimited liability or may have an indernnity which they consider sufficient. 
4 Doer the doctrine of ultre vires serve a useful purpose to-day?

The courts have attributed to the term "ultra vires" as applied to companies. a variety of meanings. and have used it to describe the following:

(a) acm of a comporate officer who has engaged in transactions cutaide the rcope of in

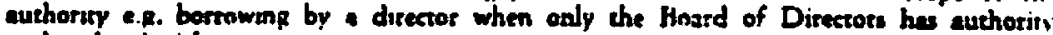
under the Articles

(h) illegal traneactions, e.e. when a company buy its own shates.

(c) trensactions brvend the powers conferxed on she company by the ototute under which it was incorporated or by tes asernornadum; e.5. a compeny empoweted to own end oper. ate a bakery engages in minuse urarius

Since the legal consequences flowing from each of these activities are not thr same. to describe all of them by the same term serves only to confuse and mislead. "Ultra vires" ought properly be used to describe onity transactions in the third category.

If we examine briefly the history of the doctrine we will see the reason for its formulation. It was held by Lord Coke in Sutton's Hospital Case" that rorporations which were created by the grant of a chartet from the king had all the powers of a natural person. The King could not withold any powers although he might set out the objects the company was to pursue and if the companv abused its powers proceedings bv way of scrre farias could be taken to forfeit the companv's charter. The doctrine of ultra vires did not apply to these common law corporations however, and the contracts entered into bi them were valid."

The railway brom which England experienced in the nineteenth century; gave rise to the incorpnration of many companies by special act of Parliament. It was tn these companies which owed their existence entirely to the inrotporat. ing statute, that the doctrine of uitra vires was first applied. The courts heid that they, unlike the common law corporations, had only the powers expressly or impliedly granted to them by the sovereign Parliament, and all other activ:. ties were forbidden." Similarly, companies formed by the registration of a memorandum of Association and Articles of Association under the company acts are held to have power to do only those things set out in their Memorandum.

A transaction entered into by a company outside the obiects of its men. orandum. and hence beyond the powers conferred upon it by the legislaturt. was nor voidable onlv, bur wholly void and of no legal effect. Since it could not be authorized it could not be ratified or confirmed, even if all the shareholders were in favour of the transaction. The obyect of the doctrine was held bv the House of Jords in Ashbury Railway Carriage and Iron Ci. v. Richei to be two-fold: (1) the protection of sharehoiders, and (2) the prorection of creditors. Yersons who might be willing to invest in a textile comp. any may be unwilling to put their money into a mining enterprise. And a lender who might be pleased to extend credit to a company engaged in the manufacture of automobiles might be laathe to see its assets dissipated ir oll exploration activities.

3(1613). 10 Co. Rep. 1 .

a beroness Wentock v. River Dee Co. (188?). 36 Ch.D. 074, et 689

4 itid

(1875). L.R. 7 H.1. 612 
Although the doctrine may have had some beneficial effeet initially, it soon proved to be something of a mired bleasing for the groups it was intended to protect. Business activities being dynamic rather than static, many businesses developed profitable lines never contemplated at the rime of incorporation. If the new activity could be regarded as reasonably incidental to the company's expressly authorized objects, the doctrine did not operate. Alteration of the company's objects clauve was permitted under the statute, genesally speaking, only to facilitate the atcainment of the company's main purpose rather than to enabie it to enter some entirely new field of business. You note the provisions of section 38 of the Alberta Companies Act in this respect. The "ultra vires" doctrine also operated to the great disadvantage of creditors who, having advanced money on an ultra vires borrowing, were precluded from suing on the contract.

To circumvent the effect of the doctrine incorporators no longer set out shortly and in general terms the activities proposed to be carried out by the company but instead, have formulated the practice of drafring long and exeremely detailed objects clauses which permitted the company to engage in any form of activity in which it might at some later date wish to engage. Al. though the undesirable consequences of the doctrine were largely overcome in this way, the original purpose was rendered nugatory. In the words of Professor Gower:"

... the whale object of the ultere vires doctrine had been largely frustrated. It bes onod to be an effective protection to anyoae and had become metely a crap for the unwery third party and a nutivase to the company itedf.

In answer to the question posed it may be fairly said that the doctrine serves no useful purpose to-day. In support of this conclusion I should like to quote from the Report of the Cohen Committee, which was appointed by the Presidene of the Board of Trade in England to consider and report what major amendments to the Companies Act of 1929 were desirable. In recommending the abolition of the doctrine, the report said in part:

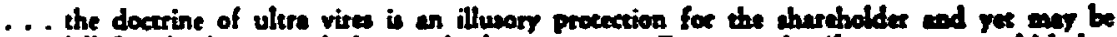

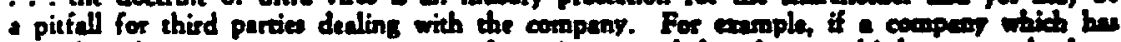
not raken the powers to carry on a tari-eb service, neverchelew does 20 , third perweres who have sold taxicabs 10 the company or have been employed to drive them man have oo legal right to recover payment from the company. We conider thes, as now applied to compenian, the ulere visen doctrine serves no positive purpose but is, on the ocher hand, - cetse of un. neceseary prolixity and reration.

5. Should the objects and powers of the Company be set out in considerable detail or set out shorlly in general terms?

The clause containing the objects of the company is one of the most important parts of the memorandum of association. Objects should state with as much clarity as possible the trades. businesses or fields of industry which the company is formed to carry on. It is advisable to use broad general terms in a shore form rather than long and detailed clauses. If the incorporators of the company desire a wide range of activities, neceasitating a number of objects clauses then there should be an interpretation clause excluding the operation of the eiusdem generis rule. 
Unce the objects have been stated the company nas consesica upon it a!! powers reasonably requisite to the attainment of these objects. Section 19 of the Companies Act states that a company shall bave the powers therein set out for the purpose of carrying out the objects of the company unless the power is expreaslv excluded. Powers should not be confused with objects. Ar. object is the trade, business or industry which the company intends to carry on A power is simply the right and authority to atran the obiects.

The confusion between objects and powers has resulted in the memosandum containing what are interpreted by the courts as objects clauses which at the time of incorporation were intended to be power clauses only. There has als: developed a body of law to the effect that a stated purpose in a memnrandun is presumed to be the trade or busuness of the company. As we are all awarc if 3 venture of a company is its trade or business then it will be taxed on the gain derived therefrom. The confusion berween power and purpose has long heen recognized:

These bes growa up a pernecsous prectece of segistering memorands of asocintion which, under the cleuse relating to objects. conten paregreph atter paragraph not opecifying ot dalimiting the propoend trede or purpose, but confusing power with purpose and indienting wery cles of ect which the corporation as power wo. The prectice is not one of recent erowch. It bes now artived at a point in which the fect is chat the function of the memorandum is enken to be not ro specify, not to dinclose. but to bury beneath a mass of wonds the real object or objeces of the company with the intent chet every conceivable form of activiny shall be found uncluded somewhere in its terms. Such a memorandum. is not, 1 think, \& complience with the Act.

Some of you may have read the recent decision in McMahon and Burns :. M.N.R.' A company, carrying on the business of underwriters, had made a private investment in one of its own securities and had recorded the same in a private investment account which it kept. On the sale of the security 2 gain was made and the gain was beld to be income. The learned judge in the Ex. chequer Court stated that the ransaction, even though regarded as an inves:ment by the caxpayer, was part of the business of the company:

The Appellang's memorandum of Aceocincion provides ior particular spectes of business anerciand in the purchase and ale of pipe-line debeanure and a protur ensued from the exercising of weth busines.

It would be interesting to know what the court would have said if the objects clause of the company had simply stated that the company's obyects were ic "carry on the buriness of an underwricer, broker or dealer" and nothung more.

My own impression is that the taxpaver would have had a better chance of success. It can be seen from the above that there is a presumption that the com. pany's business is stated in its objects chase. The taxe consequences of this pre. sumption may be costly. It must always be remembered that the Memorandum of Association can be amended so include other objects and a new company can be formed to carry on new ventures.

6. What is the nature of the restrictions on private companies and where should they be placed, in the Memorandum or in the Artirles?

A private company is defined by the Alberea Companies Acr as a comp. any which by its Memorandum or Articles: 


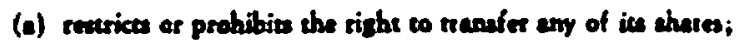

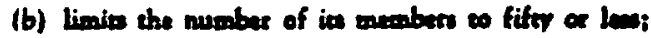

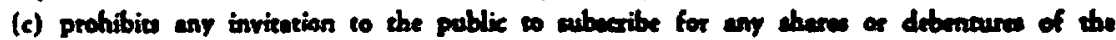
company.

The latter two of these three elements pose no difficulty and ase generally ef. fected in language almost identical to that of the Act.

It is the first element which gives rise to difficulty. The restrictions or prohibitions cover a wide field and vary from a brief provision prohibiting a transfet of shares unless the same is approved by the directors to complicated provisions granting to other shareholders what is in effect, a pre-emptive righ: co purchase shares offered for ale.

The provision placing approval in the hands of the directors is more suitable for use in the incorporation of a subsidiary where simplicity of operation is desired. Where a company is to be incorporated to carry on the business of a single proptietorahip or partnership, it would be more desirable to provide a more complete machinery for transfer. This is parriculariy important in the case of a partmership. By the very nature of the ascociation a partner may find it impractical to continue in business with his aseociates and in most instances it is not desirable to preclude him from dipposing of and realizing on his investment by an outright refusal of the Board of Directors of the company to register a transfer.

Here are some examples of clauses which might be used in the incorporation of a private company to acquire a partnership:

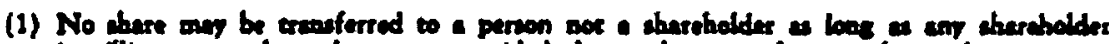
is willing to purchese the came; provided chet euch a cersufer may be mede to a nen. chereboldax if appered by the Boend of Directors.

(2) If sot epprond by the Bond of Directers the following procuduse boomes effective:

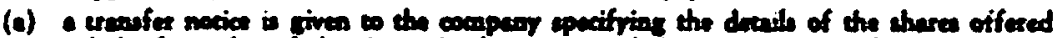
and che feir value of the chares in the opinion of the proponed trasuferer.

(b) unles otherwive determinad by a special resolution of the shercholdars the abares are

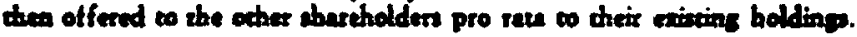

(c) a sime is un for exoptunce.

(d) the purchaing aharebolder indicates bis williamen to purchese by a further socice

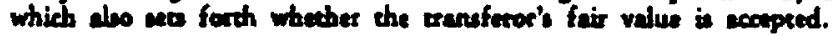

(e) if the trasaferes't fair value is not eccopted, the fair value is decercuined by the compenv's audion.

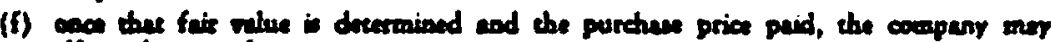
aftere the treater.

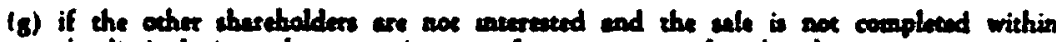

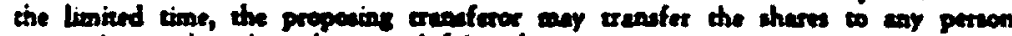
at a price nor tew then the spred fair value.

One of the main precautions in using such restrictions is that a qualified auditor must be appointed by the shareholders of the company who will be available to ascertain a fair value. In making such an appoirtment, the solicitor of the company should draw to the attencion of the auditor the nature of the rescrictions and his dury in respect of them.

A solicitor should aleo cossides the effect of death of a company share. holder. The solicitor might consider whether or nor an insurance echeme should be establiahed whereby there would be funds made available for the 
purchase of the deceased s shares thereby making monev available in :ur oat ment of succession dunes if that is a probicm.

The Alhertz Companies Act provides that restrictions may be piared rith. $r$ in the Memorandum or the Articles. The present trend in Alberta is 1.. us. the Arcicles, a trend I favour becausc:

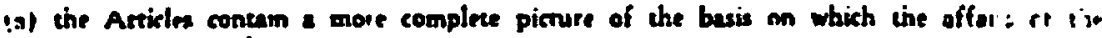
company are on ho rut:

(b) that, if an shanges hecome denisable. it mey be effected merely by opecial tesolusiss.

If, on the other hand, the restrictions are placed in tine Memorandum, the Companies Act does not have any clear method of amendment if we keep in mind s.35 of the Act which reads:

A company thall not alrer the coaditions contained in it Memerandum. exrept in the cases and in the mode and wo the exeene for which exprese provuton is ande in ebis Aci

It is suggested the only possible way to effect such amendment would be sy special resolution of the shareholders approved by the Court as 2 reorganization of share capital pursuant to 3.42 of the Ac:

7. Are the contents of Table $A$ satistactory for private and public comrasis:"

The answer is that Table. $A$ is not satisfactor;

There are nine sections in our Companies Act which use the words it , authorized hv the Articles" or words to that eifeet. Table A takes aovantaz." of one complete section and part of another, leaving therefore, eight sectunis of our Act which are not urilized if Table $A$ is used. Those sections are:

8.40 dealung with dresecion of ahase copinal.

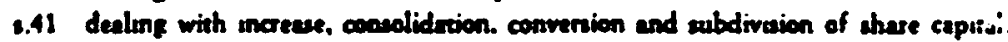

.64 which deals with the right to have a hranch regiscer oucuide the Province of Aliserta

9.75 which deals with the rithe to iusue "ahare watran:s".

0.82 (b) which permites the direceora to iacue charen at divedends.

s.100(a) which gives the company right to issue bonds. debentures, debenture stod nultsobligatsons or fully paid preference aheres upon conversuors.

s.103 (1) which gives the company the right to esthorize payment of a comusission or :s: ale of thures.

3.124 which altows a company the use of anochet sed which may have on its face the nante of the propince, otate of councry where it in to be uned.

The powers given bv ss. 40,41 , and 82 (b), I would suggest are esserria in the Articles of both private and public companies. The powers gaven :- : ss. 64 and 124 are only required where the company may do business coutsid. the province. The powers given by ss. 75 and $100(a)$ and $103(1)$ are mos. applieable to public companies.

Without going into the question of whether the Articles are dratied for th: protection of management or shaseholders it is suggested some considera:ans should be given to the following:

1. The unsertion of a clause which will permit the company en use whai ." called a "round-robin" resolution. Such a clause provides that a resol:: tion signed by all directors shall have the same force and eftect as vi: " passed at a meeting of the directors.

2. Whether the Articles should follow Table $A$ and include a provision $! c$. director to hold a share in the company. This requirement is is :sesses: 
the Articles, through 3.79 . In certain private companies it may be disadvantageous from a tax point of view. There are siruations where it is desirable to have a person a director and yet not a shareholder.

3. The Notice required for a general meering under Table $A$ is 7 dass. If the company is a public company it may in the future have its shares listed for trading on the American Stock Exchange, in which case the seven days should be changed to ten.

4. By reason of Article 62, Table A, a director who has an interest in a contract is not entitled to vote. By s.60 (a) (4) of the Act such a Director is prohibited from voting unless the articles otherwise provide.

5. Article 61 in Table A requires a resolution for the use of a seal. It is suggested that it is not advisable to have auch a requirement.

6. Where the company is a public one it is auggeated there should be some provision for indemnifying officers and directors, particularly in the case of a public company.

$\therefore$ Article 58 provides a limit on the borrowing power of the directors, and it is suggested this limit is too harsh for normal business activities.

8. Article 78 gives the company the right to declare a dividend, and it is suggested that the Directors are in a better position to decide upon the declaration of a dividend.

9. In the case of a public company it is desirable to have provicion for the appoinument of commitrees and provisions for their operation.

10. Clause 17 of Table A deals with the fee to be charged on the transfer of shares. It is auggested that if the company is a public company and its shares may be listed on the American Stock Exchange the clause should be varied to give the Directors the right to decide if a fee should be charged.

11. Article 91 provides that 2 copy of the Balance Sheet and Report of the Directors be sent to all persons entitled to receive notice of general meerings. It is submitted it should be left to the discretion of the directors whether the company should go to the expense of mailing copies to all shareholders.

12. Article 73 of Table A provides that the President be Chairman of the Board of Directors. In public companies the position is often held by another person, and this matter should be left in the discretion of the directors.

In conclusion, if Table $A$ is not to apply it should be so stated in the first of the substituted articles. Moreover if Table $A$ is used in whole or in part it should be reproduced with any changes and a copy filed in the minute book.

8. What factors should be considered in determining the share capital of a . ninpany?

The amount of authorized capieal is the first factor to be determined in

. lighe of the nature and size of the undertaking, bearing in mind the ratio 
whi:h te is desired in maintain berween rssued shart capirai an: 35 m sila., holders. The ineorporators must then ronsider:

$\vdots$ Whether shares having a nominas or par value or shar: " value are to be used in the first instance. In the usuai orivarc comps::v wil.p. oniy a nominal number of shares are issued to deline the respietive int: $\because$ : . of the participants, it is preferable to use par value shares. Howevir s\%: par value shares will be more useful if the venture is speculative and it is desire.: to place the companv in a position to be able to ussue shares as iulit in: i.t it. the first instance at a iow pricr. This is more applicable to public comrant:: where it is desirable to create initial interest and petmit the intertis $t, 0$ ipn pace with the hoped-for increase in the vaiue of the company's asspi:. Tire: would also appear to be a psuchological advantage in beang abje in nis:' 1 . par value shares for sale to the public ar a price of $\$ 1.00$ per share satili:; than shares having a Dar value of $10 \mathrm{c}$ at $\$ 1.00$.

There are two further observations that should be made with regars : . .. par value share;. Firstlv. the Alberca Companies Aci. as parcernec: $\because, i$. English Act. contains manv sections which are not readilv applicabit: io $n_{1}$, po: value shares. One porricular exampie is 3.45 with respect to the form $0: n:$ :..:: on reduction of capital. Secondiy you must make certain that the atticia: i.: the company are adapted to no par value shares. For example, with resipa. ro dividends. Article 81 of Table A states:

Subjert ro the righes of persons, if anv, entuled to shates with special righe a to ournten.i. a!l aivioiends shall be declared and pasu according to tne amuuns pard on tine shases.

The last phrase causes some difficulty where it is desirea so pav euual divid:nc nn all shares regardless of the amount paid for the individual share;

2. Arother factor to be considered is the voting rights to be atrached ii, $1 \mathrm{i}$. silares. In the case of a sole proprietorship there mav not be any necessiry in. the shares carrying different voting rughts. However, it incorporation is e:r. pioyec as a means of fixing the vaiue of the incorporator's estate tor sticcess! : durv purposes and the incorporator is to recejve preferred shares kin: i.: henericiaries raking common then the preferted should possess vc:ing ria: in:il redemprion or cancellation.

In the cace of incorporation of a partnership it may be importas: in div: mine that the shares of each participant entitle him to elect a stated numinof members to the Board of Directors.

It may be desired to employ the system of cumularive voting. This is : methoi frequently emploved in the United States and is generailv empinveri ".. the election nf directors. Under this svstem a shareholder is ailnwed to $i$ :: a numiner of votes, relared to the number or shares he holds and the numfi... vacancies. He may cast the whole number of votes available to hirs to: ." person or he may distribute them as he sees fit. Mnority sharehoiders a: given a better opportunity to secure representation under this system. Cumula. tive vortung has recently been recognized in Ontario, and provisions ate to th te iound in the Corporations Act. 195;. S.114 (1) oi our Act provide. '.. non-cumulative voting. niess utherwise novided in: 
sider our clause 73 (2b) which deals with voting requirements where a companv has difterent classes and series of shares.

3. The use of preferred shares will be conssdered in the following situations, amongst others;

(a) where incorporation is desirable for succession dury purposes and to insure continuity.

(b) where funds are to be advanced by others to an incorposator. Preferred shares will be useful in such a situation of the person advancing shares does not demand a secured position. In such a case it is destrable to make the preierred strares cumulative to insure the rerum of a pre. determined sate of return and redeemable so that the company may retire the debt.

(c) where the operations of the company indicate that its profits will be such as to permit it to take advantage of the provisions of Part 11 of the Income Tax Act. In such a case it is not necessary to be undulv concerned about the cumulative fearure.

in any event it seems that any Memorandum of Association should contain a clause permirting its shares to be issued with preferred or other rights in the manner reterred to in s. 73 (1) of the Alberta Act.

4. A fourth factor to be considered is pre-emptive rights. In the Inited States tinere is frequent use of a provision. in private companies, requiring that shares be offered to existing shareholders, pro rata. Such an offer helps co preclude dilution of minority interests. It is useful only in small private cumpanies, ano the use of such a provision is limited bv the fact that:

a) sharenolderk cannut diways prorect ther mereace if they cannot atford to puschak the addirional shares.

(b) the varierv of ahares now in use make it difficule to determine a besis on which to affer the shares.

is) the oppornunaty to acquse additional eapital and, in effect. advance the position of existing sinsreholders inecomes too testricted.

$\because$ If ival organizational stens should be taken after incorporation?

Once a cetrificate has been issued, the first meeting of the provisional directors may be set. A clause in the Articles usually states that such directors are to continue as permanent directors of the company unal replaced. At the tirst meering the organizational steps are taken in the adoption of a seal. the turn oi siare certiricate, banking resolutunns. election of additional direcrors, resignation of provisional directors, passing of a resolution regarding the registered office, and depending on the circumstances an allotment of shares.

A meeting of shareholders is generally held immediatelv after the furst meering of directors in order to adopt the necessary banking resolution enstiing the directors to borrow, hypothecate and pledge. A later meering of directors should be called if and when the agreement for the purchase of assets st the company is drafted. The returns required to be filed with the Registras, the notice of regastered office, the notice of Directors, and the recurn of allotment of shares are to he filed. In this ennnerrine: : $\$ 1$, she Art requires 
the filing with the Registrar of the appointmen: of any Manager and ans ....": in his office.

10. What are the Rerords required by the Allusira Companies Act :" it kept by the company?

The following records ate to be kept:

1. Register of Members. (5s.58.64).

2. Registet of Company's Directors and Managers (ss.81. 82).

3. Regrster of mortgages $(35.90,92 i$.

4. Bnoks of Account (ss.108-111).

5. Minure Book (s.116).

One of the pracrical problems a lawyer faces is to see that his elient is aware of certain requirements of the Act which includes keeping the above mentioned books and records. When private companies are involved records are somerimes left with the solicitor. It is impottant that the client be familiar with the requirements of the Act as non-compliance is an offence.

The problem is solved in one of two ways. One is to furnish the client with a copy of the Act. In Ontasio the Provinciai Secretary forwards an up-so-date copy of the Act upon incorporation. The other procedure is to prepare a brief memorandum on the varjous requirements of tite Act. In some ways this is more desirable as references to the Articles of the individual company can bc incorporated.

The Act does not specify the form which tine various books and registers must take. In practice, special books ate not kept and a recommended practice is to use a loose leaf book, appropriately divided. It is also suggested that the minute books of the meetings of Directors and shareholders be kept separate, as the shareholder is entitled to see the minutes of the shareholders but not of directors.

11. What are some considerations with respect to shareholders' meetings"

General meetings are dealt with specifically by 5s.112-115 of the Ace. This is a particular problem with private companies because they rarely hold general meerings. This is, of course, an offence under the Act. Everyone concerned with the practice of company law should be concerned to discove: some way to insure compliance with the Act. Firstly it provides the shareholders with some opportunity to guide the affaits of the company, and second. ly, it seems only proper that persons eaking advantage of the provisions of the Companies Act ought to be bound by its obligations.

Perhaps you will feel the best way to assure compliance with the Act is b! the incorporating solicitor raking a position as director and assuming responsibility for its books and records. It seems to mr such a course is not desirable as it infringes upon the solicitor's obligation to advise and handieaps him in that duty. The undesirability of onking an appointment as direceor is best illustrated in the case of an incorporated partnership when the old partnership disagree and the solicitor finds himself in the difficult position of having to make decisions with respect to the policy and operations of the company. 
insciar as general meetings are concemed shareholders act through resolu. ncrs and it is now common to have resolutions rigned by all those entuled to vote having the same force and effect as a resolution passed at a general meeting.

It should be pointed out that the Alberta Act discinguishes between exera. ordinary and special resolutions. The initial distinction between the two was the length of notice required to be given. By season of recent amendment the distinction does not bear the same weight and the extraordinary resolution is something of an anomaly.

The Act provides that auditors are to be appointed at and financial statements are to be laid before general annual meeting. Every incorporator should abide by these provisions. It is also customary to provide that at each annual meeting the Directors retire and the offices be filled. These three matters comprise the essential matters to be dealt with at the mecting.

Insofar as financial statements are concerned, it should be noted that these statements are to be laid before the meeting by the directors. For that reason it is desirable to have the statements approved at a prior meering of the Directors when it will also be proper to authorize the calling and holding of the general meeting.

At the time of the meering it will be necessary to see that a quorum is present and that any proxies filed are in order. It will also be necessary to conform with the requirements $2 s$ to the election of directors.

12. How are changes in share capital carried out?

A change in share capiral may be effected by:

1. Extraordinary resolution (section 40 ).

2. Resolution of the Board of Directors (Section 40).

3. Special Resolution (Section 41).

4. Special Resolution confirmed by the Court (Section 42).

The method used depends on the nature of the change to be effected. Under the first three methods the power must be given by the Articles of Assocarion. If the Articles do not contain a provision then you must proceed under section 42. Section 42 might be referred to as "the catch-all section", as it uses the words "modified the provisions contained in its memorandum so as to reorganize its share capital, in any way". To obtain a court order it is necessary to make application by Petition to the Supreme Court. Usually an affidavit is filed in support and it is suggested that such an affidavit should contain:

5. The full name of the company and date of its incorporation:

2. A statement that the Petition has been read and that it is true and correct;

3. A copy of the memorandum and any changes thereto;

4. Details of when the Notice calling the Special Meeting was mailed and a copy of the notice;

5. Verification that a copy of the said notice was mailed to all ahareholders; 
h. Information concerning the requirements of a quorum and trat $\ldots$ is ing was held and a quorum was presen!:

7. The speetal Kesolution passed at the meeting and the voting thereo:t

8 A letter from the Regustrar of Compantes or statement that tipe compan: " in good standing:

9. Where there is a reduction in capital. a last of the creditors or as sareincs: that there are onlv current accounts. The reason for the reduction slicivis also be stated.

If the application is for a reduction of share capital. the toliowing puns: should also be considerrt.

(a) That a nntice of the applicatioy ise sent to all creaitre:

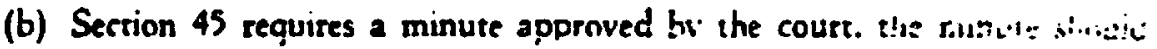
thereforr, be part of the order.

(c) If the companv is a public company and has its shares listed tor tradin: on any exchange ir is necessary to have the namr of the company cha:usici at the same tum:

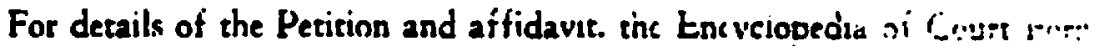
and precedents in Civil Proceedings is recommendes.

13. What are some of the consideratzons to be kept in mind in terninatm: . companv's existerite"

Firstly, there should be some advire, which would properly fo under :11: answer to question one; that is, every incorporator should be fili:; sdvised a. to the difficulties and procedure involved in terminating the existence o: : company. I have in mind. in particular, the situation facing a persur: wil:. has been a minority partner as he cannnt dissolve a business he f́ee!: 15 imrrnner. ly operated in the same way as he could dissolve a partnershi!

Dissolution is covered by Part $\mathbf{X}$ of the Alberta Companies Ar: $3 i$ is. iength. The appropriare means must be chosen for terminatior. in the each company based on the relative facts. Particular reference may be mad. s. 15k which provides for the removal from the Register of companies wnis: are in default or defunct. A careful reading of this secticr, mav ossciost:prompt and effective way of achieving termination whete there a:e or liabilizies.

One must not overiook the income tax considerations anc fastisu.at reip: ence is made to $\mathrm{s.81}$ of the Income Tax Act, wherein it is stated inat on :a: winding us ot a company, 2 dividend shall be deemed to have ceee: reccivea :

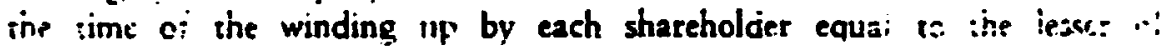

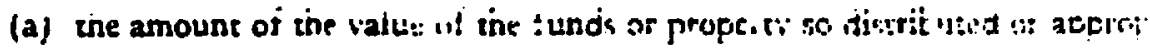
riated to then, n:

(b) his portion of the undistrebuted income then on hanc

One of the first steps then is to have the auditors of the compariy caicuate it:undistributed income of the company and to have the Taxation ? jat: sian tir : : the computation. 
The decision tinen to be made is whether to wind up the company or to , stpone the proceeding uncil the undiatributed incone can be reduced.

Another section to ikeep in mind is $8.52(2)$ of the Act which states that .yery amignee, liquidator etc, before diecributing property under his control rall obeain a certifieate that there are no outstanding taxes.

This section can be employed to determine whether a particular venture of a ompany is of is not liable to assesument prior to the actual winding up.

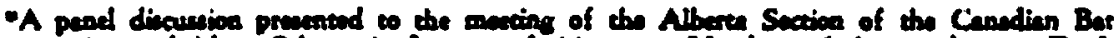
Avecietion, beld at Caleary in Jeoury of this veer. Members of the pend were: D. J.

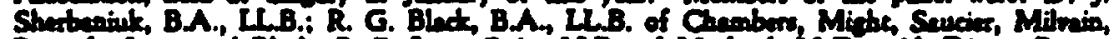
Peeced, Jones and Bleck; R. B. Love BA. LB., of Madoed, MeDermid, Diron Burs, Mccolough, Love, and Leiteh; and W. D. Didti, B.A., LL.B. of Seaford and bickie. 